\title{
Using Experimental Methods of Mechanics for Failure Prediction of Casting Pedestal
}

\author{
Lubomír Gabáni ${ }^{1}$, František Trebuňa ${ }^{2 *}$, František Šimčák ${ }^{2}$, Jozef Bocko ${ }^{2}$ and Miroslav Pástor ${ }^{2}$ \\ ${ }^{1}$ U.S. Steel Košice s.r.o, Vstupný areál U. S. Steel, 04454 Košice \\ ${ }^{2}$ Technical university in Košice, Faculty of Mechanical Engineering, Department of Applied Mechanics and Mechanical Engineering, Letná 9, 04200 \\ Košice
}

\begin{abstract}
Experimental methods of mechanics play important role in predictive maintenance and in assessment of life time of machines with long operation time. The analyses that allow to determinate and prolongate life time include quantifications of influences of production, overloading and maintenance and they allow determining limit values under which the failure of machine can occure. Such methods are important in decition process of managers of maintenance in questions of excluding of equipment from production process or in planing of maintenance. Accordingly, they contribute to elimination of results of failures and to the increasing of their reliability. In the paper is given a procedure for assessment of failure prediction and to prolongation of life time of casting pedestal.
\end{abstract}

Keywords: Numerical and experimental methods of mechanics.

\section{Introduction}

Most of damages of structures that occurred in history was not caused by failure of material, but as a result of unsuitable design, or due to breking correct technological or operation conditions, and so on. It can be stated that increasing strength of material cal lead to the reduction of weight of supporting elements of machines and equipment, but increasing of strength does not ensure at the same time increasing of material resistance against brittle fracture. The problem has to be solved complex and beside classical mechanics there have to be used solutions known from fracture mechanics, physical metallurgy as well as modern experimental and numerical methods of stress analysis [Trebuňa - Buršák, 2007].

Systematic effort of project engineers, engineers dealing with numerical computations, designers, and technologists should lead to the aim that the proposed structure will fulfil all necessary conditions, especially fulfilling the main function during prescribed life time. The structure has to fulfil conditions of effectivity, economy, and at the same time it have to be "eco-friendly". The structure has to be designed such a way that it fulfil principles of technology not only from the point of view of production, but also its assembly, controllability and reparation works. Only such a structure ensures expected benefit to the producer and operator [Dejl, 2000].

Especially last time period support us with new knowledge from the area of new structural materials, their properties in extreme conditions, new structure design, and so on. These facts require more complex view to the problems of material behaviour in operation conditions, where the analytical, numerical computational as well as experimental methods of mechanics are used for failure prediction of supporting structural members. Combination of appropriate computational and experimental methods can lead to the synergy effect and to the more effective 
procedures for design and operation of machines and equipments [Menda et al., 2013; Delyová et al., 2014; Zheng, 2015].

In the paper is presented procedure for failure analysis of casting pedestal during its twenty-year operation. It gives description of reconstructions and modifications that were proposed on the basis of analytical, numerical and experimental procedure with the aim to prolongate its safe operation for the desired life time [Trebuňa et al. 2007, 2009, 2010].

\section{Quantification of Influencies of Production Technology, Overloading and Reparation Works to the Life Time of Mechanical Elements of Heavy Supporting Structures}

Clear and unambiguous determination of term "failure" have to be determined for equipments and systems with respect to important power parameters, while at the same time conditions for satisfactorily power (function) of the equipment have to be defined. It has to be stated, in what time intervals the reparation works of equipment will be accomplished.

The parameters of measurement are usually defined according to criteria "fulfils / does not fulfil" and thez assess power attributes and the attributes of power characteristics of machines and equipments. Failures of power attributes in the form "fulfils / does not fulfil" can be quntificated and they can be defined and measured relatively easy and the most important decition is experession „yes / no". On the other side, the failure of variable function characteristics is not well-defined with respect to individual border outside of szstem function that is considered as unsatisfied. The borders of allowable function are those, under which the function can reach unappropriate level. The border "success / failure" has to be determined for every basic function property of system that has to be measured. They have to be defined clearly and unambiguously. This minimizes a chance for subjective interpretation of failure definition and consequently the manifestations of investigated failures a rationalized different way as by legitime diagnosis.

It is not enough to formulate only reliability condition. It is necessary to define also tests that will be accomplished for the verification whether the reliability condition is fulfilled. In principle, the re- liability specification should answer the following questions:

- How to provide tests of equipment/systems (determination of test conditions, e.g. environmental conditions, measures for providing tests, scope of test, conditions for equipment operation, criteria for acceptation or refusion, demands to reports and so on)?

-Who will provide tests (operator, producer, independent organization)?

- How will be the tests accomplished (development, production, real operation)?

- What kind of tests will be provided (producer of equipment, actual standards, experimental determination or prolongation of life span).

\subsection{Detection of failure of mechanical systems}

Nowadays, there is no standard used method in the area of non-destructive detection of failure from experimentally gained data relating to dynamical properties of mechanical systems. This state is caused mainly by restrictions and drawbacks of experimental techniques (incompleteness of measured data) and methods of manipulation with numerically instabile problems. In the first stage it is possible to improve detection methods by improving procedures and methods in the area of material engineering and mechatronics. In the second case, the enhancement can be accomplished by elaborating new numerical treatments or more effective formulation of failure detection problem.

The failure of mechanical system is defined as such change introduced into system that (intentionally or unintentionally) inappropriately influences actual or future state of this system. During the failure detection following groups of data are compared:

- Experimental data gained before failure of mechanical system,

- Analytical data gained from relevant mathematical model of mechanical system without failure and from experimental data gained from the system with failure.

Influence of failure to the mechanical system (MS) can be either linear or nonlinear. Linear damage is defined as a case where at the beginning linear elastic MS remains to be in that state also after deformation. Nonlinear damage is defined for the case, where at the beginning linear elastic MS is not linear and elastic after failure, i.e. it is a nonlinear 
MS.

Most procedures proposed nowadays deals with linear failure.

\subsection{Parameterization of mathematical models}

With respect to high demands given to proposed detection methods, it can be said that one candidate for fulfilling those are parametric methods of failure detection. These methods are able to support us data on the base of which the potencial failure can be not only detected, but also it can be localized and quantified [Trebuňa Šimčák, 2004].

Huge number of elaborated methods of this kind has its origin in the area dealing with correction of mathematical models. Correction is based on differences between mathematical and experimental model, while primarily it is supposed that this disproporcy is caused by inaccuracy of mathematical model. In case of detection (with a model) there is again here difference between mathematical and experimental model, while it is supposed that this difference is caused by failure in MS and accordingly that MS is the source of differences. In case of failure detection (with a model) is the mathematical theory identical with the theory of correction of mathematical models. Difference is only in the point of view to the existing difference between two groups of data. Described agreement is often the reason of insufficiently respecting of certain specific aspects of failure detection problem in comparision to the correction of mathematical models.

In such a case it is necessary to said that it is often appropriate to consider the difference between detection and correction by taking into account character of failure in one from following form:

- Mathematical model of failure (e.g. parameters describing potentially possible failure),

- Presupposed range of failure (local character of failure),

- Presupposed type of filure (weld, fatigue notch, delamination, and so on).

\section{Interventions and Improvements on the Structure of the Casting Pedestal Made on the Basis of Failure Prediction}

3.1 Function description and design of the casting pedestal

Continual production of slabs is the most spread method, where by solidification of steel are produced long steel products.

The equipment for continual casting (ZPO) Fig.1 is in the frame of product flow the strategic one. As results from the name it is based on continual (or without breakin) operation and accordingly every idle time is undesirable. In Fig. 1 is given space arrangement of casting pedestal ZPO2 with ladles.

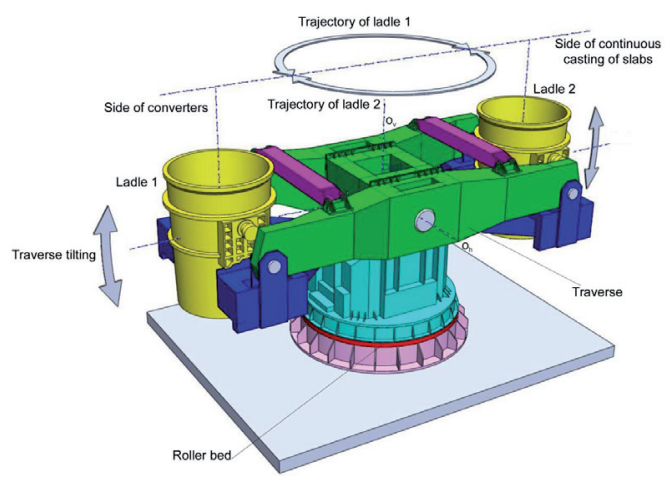

Fig. 1: Casting pedestal ZPO2 with furnace ladles.

Casting pedestal serves for positioning of casting ladles and their transport from standby (input, preparation) position into working (casting) position and vice versa (in the individual casting regimes or in regime casting over casting), for discharging of liquid steel into emergency vessels during failure of locking piece and for lifting of casting ladles during various technological operations. Casting pedestal is two-positioned, realized as lifting and rotating mechanisms with strain-gage weights. Supporting structure of casting pedestal is composed of welded steel parts the basic dimensions and shapes are proposed such a way that after positioning of full casting ladle to stanby position in the basket, the pedestal ensures the transport around axis of casting pedestal into casting position.

Weight of empty ladle is $70 t$, weight of ladle with liquid steel is $265 \mathrm{t}$.

Rotation of whole pedestal is realized by tray roll in the bottom of pedestal. Lifting is ensured by hydraulic pistons that act on evolvent teeth joined to the middle part of pedestal. Accordingly, the upper part of pedestal can be tilted which leads to lifting, or sinking of ladle. During casting of steel into tweenladle and to crystalizers on the side of ZPO, on the side of converter is positioned new ladle into basket. After ladle discharging, the 
pedestal rotates by $180^{\circ}$ and empty ladle comes to converter side, where it is teken away and full ladle comes over tweenladle. Tweenladle with capacity $45 t$ has a function of container of steel between pedestal and crystalizer, to prevent discontinuity of casting during rotation of pedestal. Untill the time of ladle discharging, new full ladle is positioned to converter side by a crane and the process repeats. The pedestal can rotate only in one direction (due to cables and hydraulic pipes in given space), it rotates $+180^{\circ}$ in one direction and by $-180^{\circ}$ back. Number of liftings of casting pedestal during casting depends on various operation conditions. The pedestal ensures realization of all necessary operations under various types of loading in the following working regimes:

with one full ladle in half-basket,

with one full and one empty ladle,

with one full ladle, second half-empty ladle (with approximately $25 \%$ of liquid steel),

with one empty ladle,

without ladle.

\subsection{History of failures of casting pedestal during its op-} eration

Weght of casted steel during whole period of work of casting pedestal is given in Tab. 1 .

According to given data the casting pedestal has processed since August 1992 untill replacement its upper part August - September 2014 alltogether 37.93 milion tons of steel. Average weight of liquid steel in the ladle was approximately 171.1 ton and the casting pedestal made approximately 221751 working cycles (that corresponds to the number of castings if we consider that 1 casting $=$ one cycle of tilting casting pedestal).

There were several changes during operation. Official start of production was with small ladles 160 t. Later, were used ladles of weight 190 t, but those did not fit basket of pedestal and that was a reason that there were diassembled after three months bars - connecting bolts, Fig.1.

During reparation at November 1997 the welds were made in locations of fractures on the casting pedestal near evolvent tooth. At the same time lubrication of central bearing - tray roll was accomplished. Approximatelly at that time a failure occurred - explosion on crystallizer (it was not possible to assess influence of explosion to the ladle on casting pedestal). It is possible that beside of liquid steel blowing from the ladle to pedestal,
Table 1: Weight of casted steel since 1992 to 2014 (replacement in August).

\begin{tabular}{|l|l|l|l|}
\hline Year & \multicolumn{1}{l}{$\begin{array}{l}\text { Number of } \\
\text { castings }\end{array}$} & \multicolumn{1}{l}{$\begin{array}{l}\text { Weight of } \\
\text { casted } \\
\text { steel [t] }\end{array}$} & \multicolumn{1}{l|}{$\begin{array}{l}\text { Average weight } \\
\text { of one casting } \\
\text { [t] }\end{array}$} \\
\hline 1992 & 1098 & 186120 & 169,5 \\
\hline 1993 & 7188 & 1292533 & 179,8 \\
\hline 1994 & 8273 & 1456219 & 176,0 \\
\hline 1995 & 8615 & 1514757 & 175,8 \\
\hline 1996 & 9072 & 1566106 & 172,6 \\
\hline 1997 & 8903 & 1552285 & 174,4 \\
\hline 1998 & 8432 & 1463969 & 173,6 \\
\hline 1999 & 8936 & 1544912 & 172,9 \\
\hline 2000 & 9340 & 1593884 & 170,7 \\
\hline 2001 & 9786 & 1637140 & 167,3 \\
\hline 2002 & 10166 & 1734945 & 170,7 \\
\hline 2003 & 11040 & 1883762 & 170,6 \\
\hline 2004 & 11514 & 1951207 & 169,5 \\
\hline 2005 & 10581 & 1812185 & 171,3 \\
\hline 2006 & 12393 & 2120358 & 171,1 \\
\hline 2007 & 12752 & 2199138 & 172,5 \\
\hline 2008 & 11503 & 1946723 & 169,2 \\
\hline 2009 & 10207 & 1710032 & 167,5 \\
\hline 2010 & 11660 & 1898676 & 162,8 \\
\hline 2011 & 10265 & 1733859 & 168,9 \\
\hline 2012 & 11301 & 1900773 & 168,2 \\
\hline 2013 & 11077 & 1905544 & 172,0 \\
\hline $8 / 2014$ & 7649 & 1327317 & 173,5 \\
\hline Sum & 221751 & 37932444 & 171,1 \\
\hline
\end{tabular}

the lifting of ladle and successive drop back to to the basket occurred.

In December 1997 the authors realized straingages measurement on the casting pedestal. The measurement was realized with the aim to detect reason of crack initiation up evolvent tooth. One possible reason was that hydraulic pistons do not act proportionally during tilting of pedestal. Accordingly fy Hydac in 1998 realized measurement of pressure in hydraulic cylinders, but this presupposition was not confirmed, because no irregularity was detected (it is truth that the difference of measurement of time/ dependent charts of individual hydraulic cylinders was not accurate enough). 
In July 1998 were detected cracks near slot wedges at length $250 \mathrm{~mm}$ that were repaired by welds. In October 1999 the change of middle part of pedestal was realized (according to internal drawings with strengthened walls of pedestal). During reparation, change of measurement system for the measurement of pedestal position was accomplished - there were applied impulse sensors, modern control system with Simatic PCS7.

One month after reparation (at November 1999) oversailing slot wedges were detected - according to drawings there was no locking for ensuring their positions, they were only given to correct positions according to drawings.

In March 2002 were repeatidly detected oversailing wedges and four bolts on the connection of middle part and traverse arms were damaged. Situation was solved by replacement of bolts and the wedges were ensures. At the same time a demand for locking of wedges arose. It was realized in November 2002 by welding of wedges into casting pedestal - the $L$ shaped structures were welded to the body of middle part.

In August 2003 replacement of 4 springs of casting pedestal has been accomplished with the prestress according to drawings.

On the basis of producer recommendation, in October 2003 assembly of 2 strenghtening bars was realized. They were disassembled in 1993, at the time of using of $190 \mathrm{t}$ ladles. However, it was necessary to shift strengthening bars by $200 \mathrm{~mm}$ away of center with respect to original documentation.

In January 2004 replacement of bolts (M48 made of material 8.8) of casting pedestal was realized. Tighting moment was $3050 \mathrm{Nm}$.

In May 2004 there was a failure on tray roll inappropriate assembly was detected. According to documentation the cage of tray roll should be jointed by bolts and welded. However, there were only bolts there and it caused that during operation the rolls were in contact. Accordingly, the failures occurred and the the journals and bolts on the rolls were changed. Some bolts were damaged and inappropriate movement of rolls led to deterioration of rolling path as well as rolls. In Fig. 2 is given a view to drive of casting pedestal that ensures its rotation.

In June 2004 the reparation of rolling path occurred. The rail was damaged, the rolls were

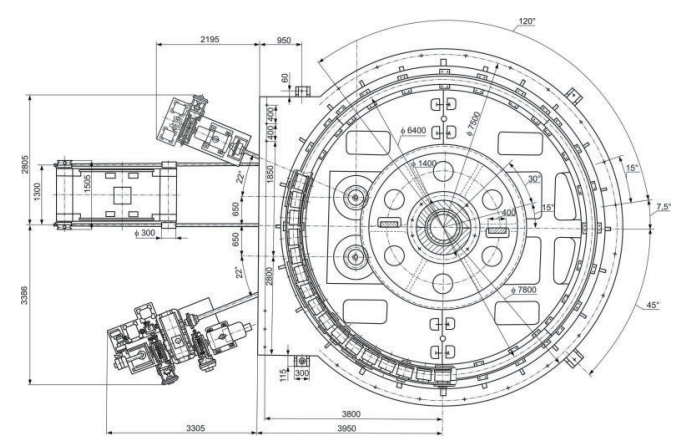

Fig. 2: Drive of casting pedestal ensuring its rotation.

deformed, radially-axial bearing has sunk and it "opens" the pedestal.

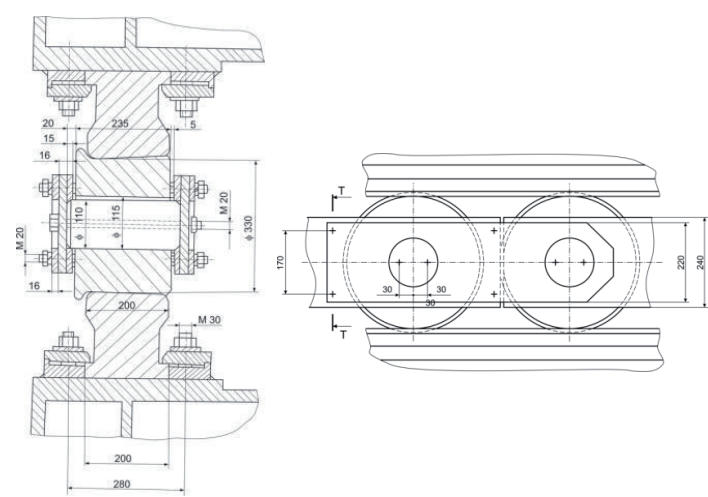

Fig. 3: Detail of tray roll.

In November 2004 the plate springs were lifted by $3 \mathrm{~mm}$, in order to eliminate deterioration of rolling path (it was realized on the bases of computations and consultation with producer).

In Februáry 2005 a failure of gearbox of pedestal was detected. It was a danger that rack gear will "catch" ribs of pedestal structure. The problem was solved by moving of gear box down by $8 \mathrm{~mm}$.

In July 2005 total exchange of rolling path was accomplished under technical inspection of producer. At the same time were changed wedges and some other parts.

In 2007 the authors has realized strain-gage measurements of pedestal because of disengage of wedges. After realization of improvement of wedge locking that was proposed by authors, the problems were not detected more. However, the slots of wedges were deformed and this caused inappropriate sounds during operation of pedestal. 
During inspection released bolts were repeatedly detected.

In September 2008 during planned outage, were realized measurements and tests of pedestal ZPO 2 by three independent teams. The locations of the highest stresses were checked by methods of defectoscopy and by capillary tests. There were detected fatigue cracks in three locations of traverse beam with lengths from 5 to $16 \mathrm{~cm}$, completely damaged bolt, and several bolts in different phases of damage. The reparation works by welding were realized during this planned outage. At the same time were replaced all damaged bolts.

On the basis of recommendation of authors were in 208 changed bolts M48 with bolts M52, connecting middle part of pedestal with traverse arms and the wedges were ensured. In order to decrease the stress levels, the empty ladle was putting on pedestal at the beginning of casting.

In 2009 and 2010 were proposed and realized measures for prolongation of pedestal life span by 5 years. There were changed plates on the most exposed locations of the structure, it was accomplished strengthening of connection of middle part and traverse arms, ansured wedges, and the measures that led to strengthening of pedestal were accomplished.

In May 2011 further measures were realized as results of inspections of $L S$. It was based on strengthening of edges of the middle part by welding of large plates, because at the beginning of 2011 the crack of length $26 \mathrm{~cm}$ was detected near upper wedge. The crack could potentially cause damage of whole traverse. In years 2012 and 2013 regular check of pedestal had been provided penetration tests of welds, check of bolts, bearings, springs, tray roll, and evolvent teeths. It was found out that evolvent teeths are deteriorated, which led to the non-uniform movement of upper part of pedestal during its tilting. All upper nuts M52 on joining of middle part - traverse arms were replaced by hydraulic nuts on one side. The Planned replacement of whole upper part of pedestal in 2013 has not been accomplished and it was shifted to year 2014.

During planned outage of pedestal in AugustSeptember 2014 the check of strength of anchorage bolts of casting pedestal was planned too on the basis of analogy with ZPO1, where during replacement in 2000 similar measures had been accomplished with design of special nuts. The check was proposed due to long-year absence of inspection of anchoring bolts ZPO2 (inspections of producer were realized several times on ZPO1). Concrete foundation was eroded by oil from hydraulic cylinders and bearings of casting pedestal. The check of anchoring bolts was also demanded from the point of view of increasing reliability of foundation (using of nuts with relieving of first screws on bolts), determination of life span of bolt joint between concrete and structure, in order to prevent possibility that after replacement of upper part of pedestal the weak part of structure will be located at foundations.

Replacement of pedestal was necessary because of its operation after planned life time (there were problems with hydraulics, evolvent teeths, there were made containers for released oil at the bottom of pedestal). The workers often said about non-standard sound during tilting.

\subsection{Realization of measures for increasing life time of supporting structure of casting pedestal}

The correct function of pedestal necessitates ensuring reliable transfer of loading from traverse beams to the middle part and through evolvent teeths to hydraulic cylinders. Accordingly, it was necessary to increase coordinated complex work of bolts and wedges between traverse and the middle part. It necessitates increasing of reliability of force transfer through wedges and this result to demand for increasing of stability of wedge positions (without allowance between slots and wedges). Such a measure should be as simple as possible and it should allowe to visually check position of wedges. The measure is based on closing of upper wedges by backstop with nut and jack nut, Fig. 4.

Increasing of loading transfer safety by wedges led to application of additional prestress in bolts. The prestress in original bolts M48 was too small even if the prestress was $300 \mathrm{kN}$. The nuts can have prestress $510 \mathrm{kN}$ in case of screw lubrication as well as lubrication of connection nut - washer, washer - flange by lubricant paste MoS2 and torque 3060 $\mathrm{Nm}$. The holes for bolts are of diameter $56 \mathrm{~mm}$ so that it was possible use bolts M52 made of material 8.8. On bolts was used torque $3900 \mathrm{Nm}$ that leads to prestress $600 \mathrm{kN}$. This measure increased force transfer through bolt connection by $20 \%$ (for real value of friction coefficient $f_{p}=0.15$ between sur- 

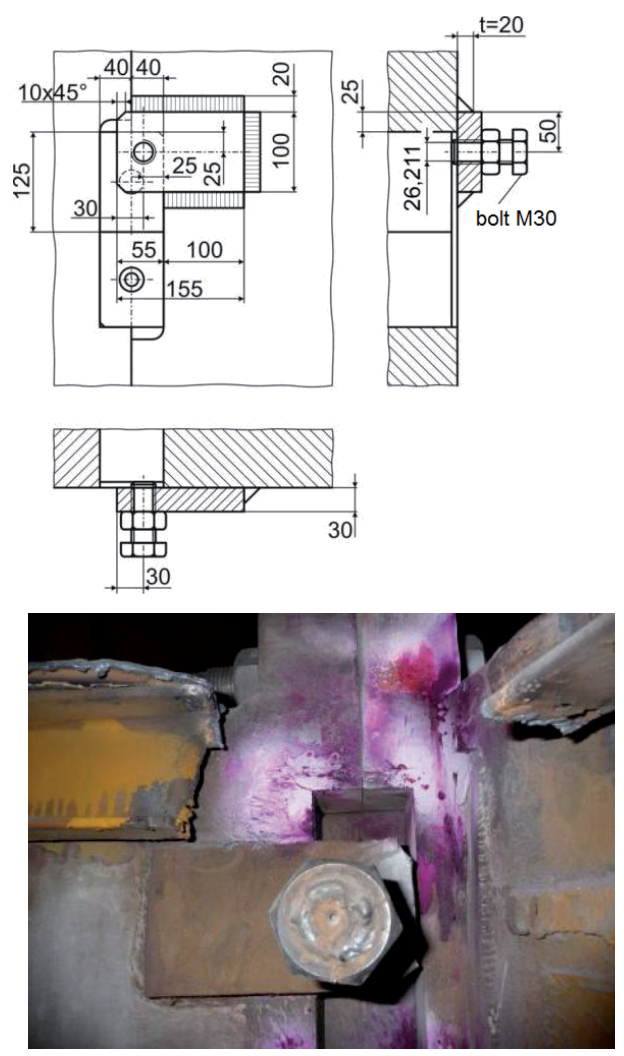

Fig. 4: Ensuring safety of slot wedges.

faces, the bolt connection could transfer only $18 \%$ of loading and the wedges 82\%).

On the basis of detail analysis can be stated that the highest dynamic effects in supporting members are at the time interaval when the ladle with liquid steel is in one half-basket and the second half-basket is empty. This state occurs always during positioning of the first calsing ladle into pedestal and its rotation from standby position to the working one. There were proposed two possible solutions how to prevent this inappropriate state:

- The first one is connected with using of empty ladle in the second half-basket. The difference between weights in both half-baskets becomes smaller than 190 - 195 tons and the first condition will be fulfilled.

\section{- The second solution that is not very suitable form} operation point of view lies in demand to have always maximum 120 tons of liquid steel in the first ladle.

In both cases is fulfil condition determined by computations.

On the basis of detail analyses accomplished at 2009 was found out that without reduction of stress amplitudes by above mentioned measures, the life tome of casting pedestal should be decreased from 3.2 years to 0.8 year and the life time of casting pedestal should end at May 2010. This prediction was concluded by real state of pedestal and initiation of very long cracks in locations of wedge connections (see Fig.5) and in traverse arms (Fig.6) in locations of their connection to the middle part.

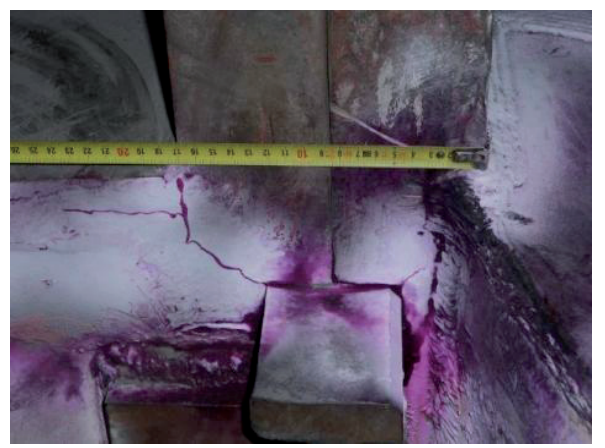

Fig. 5: Cracks on the middle part and on the traverse beam in location of slot wedge.

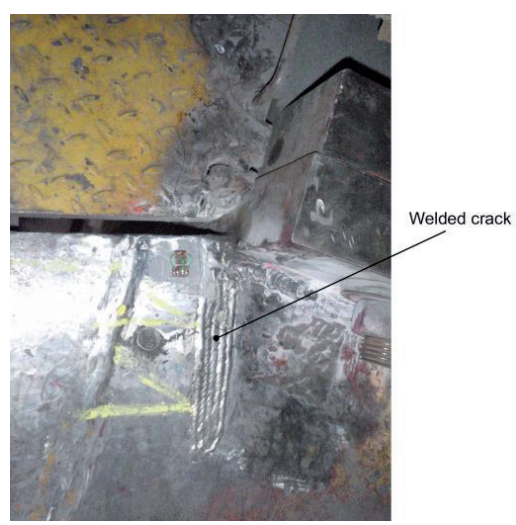

Fig. 6: Welded crack on traverse beam.

With respect to the creation of cracks in the area of wedge joints during strengthening of connections of traverse beam with middle part, it was supposed that wedges do not work, i.e. the forces are transmitted only through bolt and weld joints.

In Fig.7 is given a half-model of middle part and pedestal traverse with proposed strenghtenings.

The analysis of stress states was accomplished by the finite element method by successive adding or modification of strengthened supporting members until state when maximal stresses in quasistatic analysis did not reach from above the stresses in 
original structure without working wedge connection. The modifications change also locations of maximal stresses that could lead to crack initiation in new locations of casting pedestal.

In the frame of reparations proposed by authors, the strengthening of foundation plate of tray roll of pedestal had been accomplished too. This measure was realized only in upper part, see Fig.8.
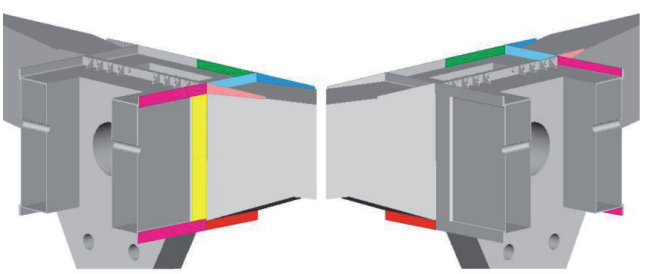

Fig. 7: Half model of the middle part and pedestal traverse with proposed strengthening.

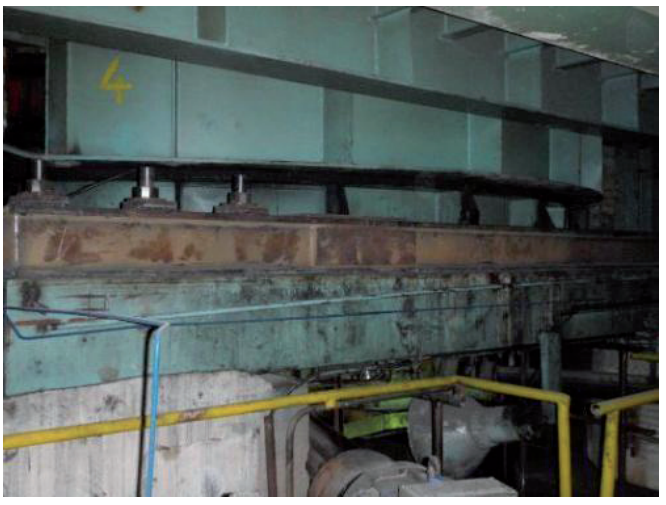

Fig. 8: Strengthening of foundation plate of pedestal in the top part.

The proposed measures do not allow longtime operation and they necessitate lar check of technical state including strain-gage measurement after finished structure modifications [Kobayashi, 1993; Trebuňa - Šimčák, 2007].

The locations of extreme failure cumulations on the traverse beams (near cracks) were replaced by new material (Fig.9). In these locations were not cracks after reparation works and these can be considered to be suitable for operation.

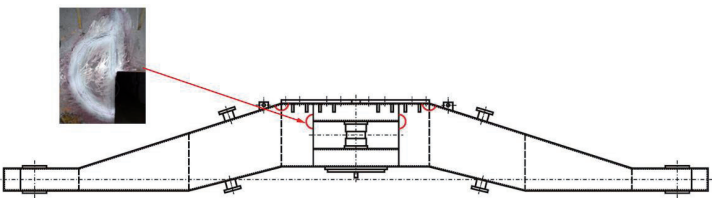

Fig. 9: Locations on traverse beam that are replaced.
Realization of described measures ensured safe operation of casting pedestal until the time of planned replacement of pedestal supporting structure (year 2014).

\section{Conclusions}

Fevelopment and using of experimental methods for the assessment of safe operation of equipments in mechanical and metallurgical industry is a necessity. The pressure for decreasing of costs the companies are oriented to effective using of production equipment, detection of technical state, avoiding failures that altogether can lead to increasing of life time and reliable function of equipment.

Various experimental methods as a tool for failure prediction were used during damage of equipment or with the purpose to assess and prolongate life time of strategic parts. The aim to save money for a new pedestal was used analytical, numerical as well experimental methods and the life time was prolongated by appropriate measures. Realization of proposed measures prolongated life time of equipment by five years and this led to significant economic effects.

\section{Acknowledgements}

The authors would like to express their gratitude to Scientific Grant Agency VEGA for the support of this work under projects No. 1/0937/12 and No. 1/0393/14.

\section{References and notes}

[1] Trebuňa, F. - Buršák, M. Medzné stavy - lomy. Grafotlač Prešov, Prešov, 2002, ISBN 8071653624

[2] Dejl, Z. Konstrukce strojů a zařízení I. Montanex, Ostrava, 2000.

[3] Menda, F. - Trebuňa, F. - Šarga, P. New Method of Residual Stress Evaluation and its Advantages in Comparison with More Common Hole-drilling Method. In: Acta Mechanica Slovaca. Roč. 17, č. 4 (2013), s. 64-70, ISSN 1335-2393

[4] Delyová, I. - Sivák, P. - Hroncová, D. - Kováč, J. Stress analysis of the thin-walled vessels. In: Applied Mechanics and Materials. Vol. 611 (2014), p. 273-278, ISSN 1660-9336 Spôsob prístupu: www.scientific.net/AMM

[5] Zheng, S. et al. Failure analysis of frame crack on a widebody mining dump truck. In: Engineering Failure Analysis Vol. 48 (2015), p. 153-165, ISSN 1350-6307

[6] Trebuňa, F. et al. Analýza a určenie životnosti liaceho stojana na ZPO 2 U.S.Steel Košice. SjF TU v Košiciach, Košice, jún august 2007 
[7] Trebuňa F. et al., Riešenie predlženia životnosti liacieho stojana s využitím záverov doterajších analýz a návrhy úprav pre predlženie životnosti liacieho stojana. SjF TU, Košice, 2009

[8] Trebuňa, F. et al. Technická pomoc pri realizácii opatrení na zabezpečenie predĺženia životnosti liacieho stojana na ZPO II. SjF TU v Košiciach, Košice, jún 2010

[9] Trebuňa, F. - Šimčák, F. Odolnost' prvkov mechanických sústav. EMILENA, Košice, 2004

[10] Kobayshi, A. S. Handbook on Experimental Mechanics, VCH Verlagsgesellschaft mbH, Weinheim, Germany, 1993

[11] Trebuňa, F. - Šimčák, F. Príručka experimentálnej mechaniky. Typopress, Košice, 2007

\section{Biographical notes}

Lubomír Gabáni, Ing., (1968). He graduated at the Faculty of Mechanical Engineering, Technical University of Košice in 1991. Since 1991 he works in the U.S.Steel Košice a.s. in manager positions relating to reparation works. Since November 2011 he is Team Manager Steelworks Maintenance Reliability.

František Trebuňa, Dr.h.c. mult. prof. Ing. CSc., (1947) is a professor of Applied mechanics, Dean of the Faculty of Mechanical Engineering of Technical university of Košice. He is author of 12 monographs, 13 university textbook, special book publications, 12 university notebooks and more than 350 publications in journals and conference proceedings in Slovakia and abroad. He is also author of important projects and engineering works. His professional and scientific orientation is oriented to experimental and numerical methods of mechanics, prediction lifetime of structure, stress and strain analysis, photoelasticimetry, redistribution of stresses, modal analysis. He received several prizes at home and abroad. He received three honorary Doctor Honoris Causa (Dr.h.c.) including two from foreign universities for the development of applied mechanics and mechatronics and last year he received Honorary Doctorate of Letters (For the extraordinary contribution in the area of creation, development and publication activity in the scientific branches of applied mechanics and mechatronics), IBC Cambridge, England. At the beginning of 2014 he received State prize he got "Honour of Ludovit Štur of the 2nd order". Prof. Trebuña is a member of several Scientific councils on technical universities in Slovakia and abroad and member of editorial boards of journals.

František Šimčák, prof. Ing. CSc., (1947) is a professor of Applied mechanics, Head of the Department of Applied Mechanics and Mechanical Engineering. He is author of 8 monographs, 11 university textbook, 6 university notebooks and more than 250 publications in journals and conference proceedings in Slovakia and abroad. He is co-author of important projects and engineering works. He received several prizes due to his scientific results. His professional and scientific orientation is oriented to strength and stiffness analysis of thin-walled elements and structures, computational and experimental stress analysis of structural elements made of classical and composite materials, plastic properties of steel sheets and lifetime of structures. He is a member of Scientific council of the Faculty of Mechanical Engineering, Technical University of Košice.

Jozef Bocko, prof. Ing., CSc., (1959) is a professor of applied mechanics. He is author of 2 monographs, 9 university textbook and more than 200 publications in journals and conference proceedings in Slovakia and abroad. He is author and co- author of important projects and engineering works. His professional and scientific interests are oriented to the finite element method, nonlinear mechanics, shell theory, application of Lie groups in mechanics. He is a member of Scientific council of the Faculty of Mechanical Engineering, Department of Applied Mechanics and Mechanical Engineering, Technical University of Košice and member of council of Slovak Association of Mechanics by Slovak Academy of Sciences.

Miroslav Pástor, doc. Ing., PhD., (1975) is a associated professor on the Department of Applied Mechanics and Mechanical Engineering. In 2008 he received PhD. in the field of Applied mechanics. In 2013 he habilitated in the area of Applied mechanics. He is author of 2 monographs, 3 university textbook and more than 60 publications in journals and conference proceedings at Slovakia and abroad. He is co-author of important projects and engineering works. He made remarkable work on the building of laboratories and on publication of monographs and university textbook at the department. His professional and scientific orientation is oriented to experimental of mechanics, prediction lifetime of structure, stress and strain analysis, photoelasticimetry. He is a member of Slovak Association of Mechanics by Slovak Academy of Sciences. 